RESEARCH ARTICLE

\title{
Alcoholysis Versus Fission of the Ester Group During the Reaction of Dialkyl Phenylphosphonates in the Presence of Ionic Liquids
}

\author{
Nikoletta Harsági ${ }^{1}$, Csilla Bertha ${ }^{1}$, Nóra Zsuzsa Kiss ${ }^{1}$, Réka Henyecz $^{1}$, Petra Regina Varga ${ }^{1}$, \\ Péter Ábrányi-Balogh ${ }^{2}$, László Drahos ${ }^{3}$ and György Keglevich ${ }^{1, *}$
}

\begin{abstract}
${ }^{1}$ Department of Organic Chemistry and Technology, Budapest University of Technology and Economics, 1521 Budapest, Hungary; ${ }^{2}$ Research Centre for Natural Sciences, Medicinal Chemistry Research Group, 1117 Budapest, Hungary; ${ }^{3}$ Research Centre for Natural Sciences, MS Proteomics Research Group, 1117 Budapest, Hungary
\end{abstract}

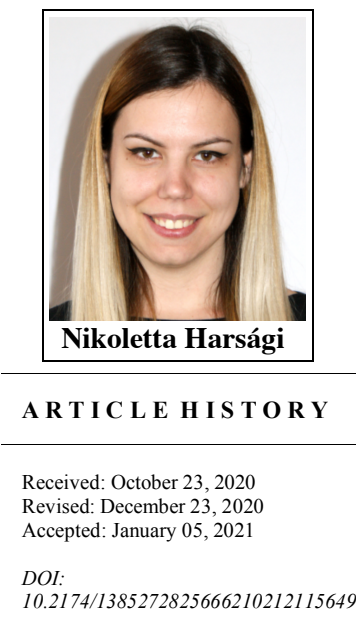

\begin{abstract}
In the microwave-assisted alcoholysis of dialkyl phenylphosphonates performed in the presence of suitable ionic liquids, such as $[\mathrm{bmim}]\left[\mathrm{BF}_{4}\right]$ or $[\mathrm{bmim}]\left[\mathrm{PF}_{6}\right]$, affording the phosphonate with mixed alkoxy groups and the fully transesterified product, the fission of the phosphonate function to the ester-acid or diacid moiety was inevitable. Moreover, in the presence of $[\mathrm{emim}]\left[\mathrm{HSO}_{4}\right]$, the reaction could be performed to afford the phosphonic esteracid with a selectivity of $66 \%$ and the diacid with a selectivity of $97 \%$. The ester-acids provided by the new protocol may be valuable intermediates.
\end{abstract}

D.

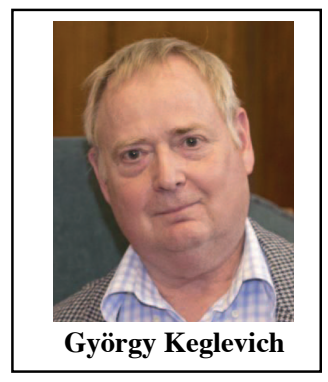

Keywords: Dialkyl phosphonates, microwave, alcoholysis, ionic liquid, phosphonic ester-acid, phosphonic acid

\section{INTRODUCTION}

The $P$-esters, including phosphinates and phosphonates, are important starting materials or intermediates in organic syntheses $[1$, 2] that may be prepared by the reaction of the corresponding phosphinic chloride or phosphonic dichloride, respectively, with alcohols [2, 3]. An up-to-date option is a microwave (MW)assisted, ionic liquid (IL)-catalyzed direct esterification of phosphinic or phosphonic acid with alcohols $[4,5]$. An alternative possibility for the preparation of $P$-esters is the Arbuzov reaction [1]. Modification of the $P$-esters by alcoholysis (transesterification) may also be a good choice [6-8], which is an analogous process with biodiesel production [9]. Both the alcoholysis of phosphinates [10] and that of phosphonates [11] have been studied by the senior author of this paper and Kosolapoff, respectively. The transesterification of dialkyl phosphites ( $H$-phosphonates) was investigated by different groups headed, among others, by Aitken and Lewkowski [11-14]. The two-step transformations of dialkyl phosphites were also performed under MW conditions $[15,16]$. The dialkyl phosphites with two different alkyl groups are the intermediates of these processes that are valuable species due to the asymmetric Pcenter. Moreover, continuous flow accomplishments were also elaborated $[17,18]$. The transesterification of dialkyl phosphites

*Address correspondence to this author at the Department of Organic Chemistry and Technology, Budapest University of Technology and Economics, 1521 Budapest, Hungary; Tel: +36-1-463-1111(5883); Fax:+36-1-463-3648; E-mail: keglevich.gyorgy@vbk.bme.hu with di-, tri- and tetrahydroxy compounds, such as ethylene glycol, diethylene glycol, triethylene glycol, 1,5-pentanediol, 1,6-hexanediol, 1,10-decanediol, resorcinol, hydroquinone, glycerol, or pentaerythriol is of importance, as these polycondensations lead to Pfunctionalized polymers [19-22]. The potential of MW irradiation in the synthesis of polymers was also underlined [23].

The hydrolysis of P-esters (phosphinates and phosphonates) is mostly carried out under acidic conditions and is of immense importance [24-26]. Till date, the hydrolysis of phosphonates cannot be performed selectively to afford the ester-acid [26].

In this paper, we summarize the results of our investigations on the MW-assisted, IL-catalyzed alcoholyses and related reactions of dialkyl phenylphosphonates. The beneficial effect of ILs as catalyst/additives is well-known in a wide range of reactions [27].

\section{RESULTS AND DISCUSSION}

The first model for the attempted alcoholyses was the reaction of diethyl phenylphosphonate (1) with $n$-butanol. The alcoholyses were performed under MW irradiation, applying the alcohol in a 15 fold quantity. The results obtained by ${ }^{31} \mathrm{P}$ NMR spectral and LCMS analysis are summarized in Table 1 . There was no reaction after a $2 \mathrm{~h}$ irradiation at $200^{\circ} \mathrm{C}$ (Table 1/Entry 1). In search of promoting the reaction, the catalytic effect of different ionic liquids (ILs) was tested. After reacting the components at $200{ }^{\circ} \mathrm{C}$ for $3.5 \mathrm{~h}$ in the presence of $10 \%$ of $[\mathrm{bmim}]\left[\mathrm{BF}_{4}\right]$, the mixture contained unreacted starting material (1) together with the phosphonate with different 
alkoxy groups (2) and the fully transesterified product 3 (the three components all together: 39\%), along with phosphonic ester-acids 4 and 5 (all together: $55 \%$ ), as well as $6 \%$ of the phosphonic acid (6) (Table 1/Entry 2). The ${ }^{31} \mathrm{P}$ NMR shifts of the different dialkyl phosphonates (starting material (1), intermediate (2) product (3)), as well as, that of ester-acids $\mathbf{4}$ and $\mathbf{5}$ were overlapped. Although the effect of ILs to cleave the phosphinate function to the acid moiety is not unknown [6], the drastic effect of $[\mathrm{bmim}]\left[\mathrm{BF}_{4}\right]$ to result in the formation of $55 \%$ of ester-acids $\mathbf{4}$ and $\mathbf{5}$ was surprising. Performing the reaction at $220^{\circ} \mathrm{C}$ for $2 \mathrm{~h}$, the proportion of phosphonates 2 and $\mathbf{3}$, phosphonic ester-acids $\mathbf{4}$ and $\mathbf{5}$, as well as phosphonic acid $\mathbf{6}$ was $8 \%, 19 \%, 3 \%, 56 \%$ and $14 \%$, respectively, that was almost comparable with the previous results (Table 1/Entry 3). Allowing a longer reaction time of $3.5 \mathrm{~h}$ at $220^{\circ} \mathrm{C}$, there was practically no change in the product composition (Table 1/Entry 3 /footnote "d"). The effect of $[\mathrm{bmim}]\left[\mathrm{PF}_{6}\right]$ at $200{ }^{\circ} \mathrm{C}$ for $2 \mathrm{~h}$ was rather similar to that of [bmim] $\left[\mathrm{BF}_{4}\right]$ at $200{ }^{\circ} \mathrm{C}$ for $3.5 \mathrm{~h}$ (the quantity of $\mathbf{2}+\mathbf{3}$ was $38 \%$, that of $4+5$ was $54 \%$, while that of $\mathbf{6}$ was $8 \%$; entries 4 and 2 of Table 1 are to be compared). After a longer reaction time of $3.5 \mathrm{~h}$, the proportion of the esters ( 2 and 3 ) decreased to $27 \%$, while that of esteracids 4 and 5 , as well as diacid $\mathbf{6}$ increased to $61 \%$ and $12 \%$, respectively (Table 1/Entry 5). [Emim] $\left[\mathrm{HSO}_{4}\right]$ was the third additive tested. Irradiating the components at $200{ }^{\circ} \mathrm{C}$ for $2 \mathrm{~h}$, the fraction comprising 1-3 was formed in 43\% (unreacted starting material 1: $38 \%$, mixed ester 2 and 3: 5\%), the ester-acids $4+5$ in 51\% (4: 5\% and 5: 46\%), while acid 6 in 5\% (Table 1/Entry 6). Prolongation of the reaction time to $3.5 \mathrm{~h}$ led to a composition of $23 \%, 66 \%$, $11 \%$ for fractions $\mathbf{1 - 3}$, ester-acid $\mathbf{5}$, and acid $\mathbf{6}$, respectively (Table 1/Entry 7). The predominating formation of the phosphonic ester-acid $\mathbf{5}$ is noteworthy. At $220^{\circ} \mathrm{C}$ after $2 \mathrm{~h}$, the composition was $37 \%, 58 \%, 5 \%$ for the fractions $\mathbf{1 - 3}, \mathbf{4} / \mathbf{5}$ and $\mathbf{6}$, respectively
(Table 1/Entry 8). After a longer irradiation time of $3.75 \mathrm{~h}$, only $29 \%$ of the ester-acids 4 and 5, along with $71 \%$ of the diacid 6 formed the mixture (Table 1/Entry 9). It is worth noting that we worked under anhydrous conditions. One may see that it is possible to fine-tune the outcome of the reaction by selecting the appropriate IL, temperature and reaction time.

To summarize our findings, the phenylphosphonate (1) was converted to phosphonate $\mathbf{3}$ via intermediate $\mathbf{2}$. However, intermediate $\mathbf{2}$ may be transformed to ester-acids $\mathbf{4}$ and $\mathbf{5}$, while ester $\mathbf{3}$ to ester-acid 5. Further alkoxy fission of ester-acids $\mathbf{4}$ and $\mathbf{5}$ afforded phosphonic acid 6. The fission of the alkoxy group of the phosphonic derivative $(\mathbf{2}, \mathbf{4}$, or 5 ) may be caused by the attack of the $\mathrm{BF}_{4}{ }^{-}, \mathrm{PF}_{6}{ }^{-}$, or $\mathrm{HSO}_{4}{ }^{-}$anion of the IL. The formed salt is converted to the acid $(\mathbf{4}, \mathbf{5}$ or $\mathbf{6})$ on workup. The dry "hydrolysis" is a known procedure [28]. Ester-acid 4 may also be formed directly from the starting phosphonate (1) (Scheme 1).

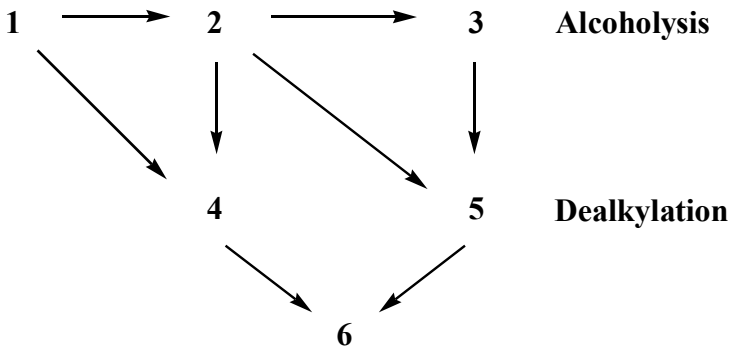

Scheme 1. Possible routes for the formation of the intermediates/products

In order to simplify the previous reaction leading to the mixture of five products, we wished to focus only on the fission of the alkoxy group(s); therefore, the next experiments were carried out in

Table 1. The alcoholysis of diethyl phenylphosphonate (1) with butanol accompanied by dealkylation in the presence of ionic liquids.

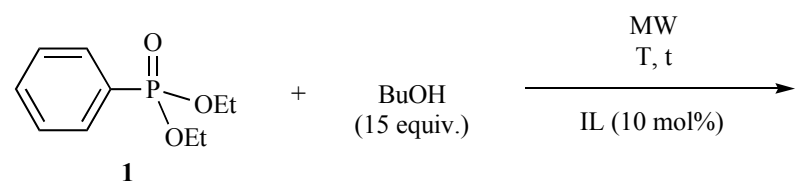

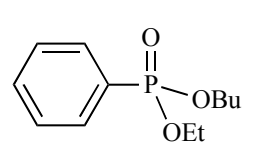

2<smiles>CCCCOP(=O)(OCCC)c1ccccc1</smiles>

3

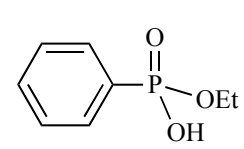

4

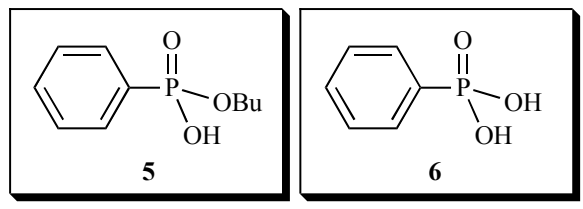

\begin{tabular}{|c|c|c|c|c|c|c|c|c|c|}
\hline \multirow[b]{2}{*}{ Entry } & \multirow[b]{2}{*}{ IL } & \multirow{2}{*}{$\begin{array}{c}\mathrm{T} \\
\left({ }^{\circ} \mathrm{C}\right)\end{array}$} & \multirow{2}{*}{$\begin{array}{c}\text { t } \\
(\mathbf{h})\end{array}$} & \multicolumn{6}{|c|}{ Composition $(\%)^{a, b}$} \\
\hline & & & & $\begin{array}{c}1 \\
M+H=215^{c}\end{array}$ & $\begin{array}{c}2 \\
M+H^{2}=243^{c}\end{array}$ & $\begin{array}{c}3 \\
\mathbf{M}+\mathbf{H}^{=}=271^{c}\end{array}$ & $\begin{array}{c}4 \\
M+H=187^{c}\end{array}$ & $\stackrel{5}{M+H^{=}=215^{c}}$ & $\begin{array}{c}6 \\
M+H=159^{c}\end{array}$ \\
\hline 1 & - & 200 & 2 & $100^{a}$ & \multicolumn{2}{|c|}{0} & \multicolumn{2}{|c|}{0} & 0 \\
\hline 2 & {$[\mathrm{bmim}]\left[\mathrm{BF}_{4}\right]$} & 200 & 3.5 & \multicolumn{3}{|c|}{$39^{a}$} & \multicolumn{2}{|c|}{$55^{a}$} & 6 \\
\hline 3 & {$[\mathrm{bmim}]\left[\mathrm{BF}_{4}\right]$} & 220 & $2^{d}$ & 0 & $8^{b}$ & $19^{b}$ & $3^{b}$ & $56^{b}$ & $14^{b}$ \\
\hline 4 & {$[\mathrm{bmim}]\left[\mathrm{PF}_{6}\right]$} & 200 & 2 & 0 & $16^{b}$ & $22^{b}$ & $43^{b}$ & $11^{b}$ & $8^{b}$ \\
\hline 5 & {$[\mathrm{bmim}]\left[\mathrm{PF}_{6}\right]$} & 200 & 3.5 & \multicolumn{3}{|c|}{27} & \multicolumn{2}{|c|}{61} & 12 \\
\hline 6 & {$[\mathrm{emim}]\left[\mathrm{HSO}_{4}\right]$} & 200 & 2 & $38^{b}$ & $4^{b}$ & $1^{b}$ & $5^{b}$ & $46^{b}$ & $6^{b}$ \\
\hline 7 & {$[\mathrm{emim}]\left[\mathrm{HSO}_{4}\right]$} & 200 & 3.5 & $14^{b}$ & $6^{b}$ & $3^{b}$ & 0 & $66^{b}$ & $11^{b}$ \\
\hline 8 & {$[\mathrm{emim}]\left[\mathrm{HSO}_{4}\right]$} & 220 & 2 & \multicolumn{3}{|c|}{37} & \multicolumn{2}{|c|}{58} & 5 \\
\hline 9 & {$[\mathrm{emim}]\left[\mathrm{HSO}_{4}\right]$} & 220 & 3.75 & \multicolumn{3}{|c|}{0} & \multicolumn{2}{|c|}{29} & 71 \\
\hline
\end{tabular}

${ }^{a}$ On the basis of relative ${ }^{31} \mathrm{P}$ NMR integrals

${ }^{b}$ On the basis of combined ${ }^{31} \mathrm{P}$ NMR and LC-MS analysis

${ }^{c}$ Confirmed by LC-MS

${ }^{d}$ Practically, there was no change after further irradiation $(\Sigma 3.5 \mathrm{~h})$ 
the alcohol having an identical alkyl group as the phosphonate. In the first series of experiments, diethyl phenylphosphonate (1) was irradiated at $160{ }^{\circ} \mathrm{C}$ in ethanol in the presence of $10 \%$ of [bmim] $\left[\mathrm{BF}_{4}\right]$ and $[\mathrm{emim}]\left[\mathrm{HSO}_{4}\right]$ (Table 2/Entries 1 and 2). In the first case, there was no reaction, however, the second run took place in a conversion of $42 \%$, furnishing $\mathrm{PhP}(\mathrm{O})(\mathrm{OEt})(\mathrm{OH})$ (4) and $\mathrm{PhP}(\mathrm{O})(\mathrm{OH})_{2}(6)$ in $38 \%$ and $4 \%$, respectively. After a prolonged reaction time of $6 \mathrm{~h}$, there was only a little increase in the conversion (49\%) (Table 2/Entry 3 ). It can be concluded that the $\mathrm{PhP}(\mathrm{O})(\mathrm{OEt})_{2} / \mathrm{EtOH}$ model is not suitable due to the limit in the temperature that is the consequence of the volatility of ethanol.

The $\mathrm{PhP}(\mathrm{O})(\mathrm{OBu})_{2} / \mathrm{BuOH}$ system allowed a higher temperature of $200{ }^{\circ} \mathrm{C}$. However, using [bmim] $\left[\mathrm{BF}_{4}\right]$, there was again no reaction after an irradiation time of $2 \mathrm{~h}$ (Table 3/Entry 1). $[$ Emim $]\left[\mathrm{HSO}_{4}\right]$ was again more efficient as an additive after a reaction time of 2 and $2.5 \mathrm{~h}$ (Table 3/Entries 2 and 3). After running the reaction for $3.5 \mathrm{~h}$, no starting material remained in the mixture, and the proportion of the monoacid (5) and diacid (6) was 37\% and $63 \%$, respectively (Table $3 /$ Entry 4 ).

There is also a possibility that ester-acids $\mathbf{4}$ and $\mathbf{5}$, as well as diacid 6 are also formed in the presence of $\left[\mathrm{bmim}^{-}\left[\mathrm{BF}_{4}\right] / \mathrm{EtOH}\right.$ or $\mathrm{BuOH}$, but under the conditions of $160 / 200{ }^{\circ} \mathrm{C}$, species 4-6 are esterified back. Earlier studies revealed that $[\mathrm{bmim}]\left[\mathrm{BF}_{4}\right]$ was the best additive for direct esterification [5].
The above experiments were carried out under anhydrous conditions. The following question emerged: what would happen if the reactions were performed in the presence of a small amount of water. Hence, dibutyl phenylphosphonate $\mathbf{3}$ was irradiated in the presence of $10 \% \mathrm{IL}$ and 1 equivalent of water at $200{ }^{\circ} \mathrm{C}$ for $2 \mathrm{~h}$. The fission of the hydroxy groups was inhibited, as only $24 \%$ of esteracid 5 and $8 \%$ of diacid $\mathbf{6}$ were formed (Table 3 , footnote "c" to Entry 2). This proves that no hydrolysis is involved.

In the next stage, the fission of dialkyl phenylphosphonates was attempted in a solvent-free manner. The results obtained in the experiments with diethyl phenylphosphonate $\mathbf{1}$ are shown in Table 4. Applying $10 \%$ of $[\mathrm{bmim}]\left[\mathrm{BF}_{4}\right]$ at $200{ }^{\circ} \mathrm{C}$ for $3.5 \mathrm{~h}$, the conversion was only $30 \%$ (Table $4 /$ Entry 1 ). Irradiation at $220^{\circ} \mathrm{C}$ for $4 \mathrm{~h}$ allowed the conversion of $79 \%$ with a $21-58 \%$ ratio of the ester-acid (4) and diacid (6) (Table 4/Entry 2). After a $6.5 \mathrm{~h}$ reaction time, the conversion was complete, and the mixture contained $27 \%$ of the ester-acid (4) and $73 \%$ of the diacid (6) (Table 4/Entry 3 ). The use of $[\mathrm{emim}]\left[\mathrm{HSO}_{4}\right]$ as an additive was more efficient. After a treatment at $200{ }^{\circ} \mathrm{C}$ for $2 \mathrm{~h}$, the composition of the mixture was $19 \%$ (1), 36\% (4), and 45\% (6) (Table 4/Entry 4). Following a 5 h reaction time, there was no starting material (1) in the mixture that contained $13 \%$ of ester-acid 4 and $87 \%$ of diacid 6 (Table $4 /$ Entry 5 ). Increasing the temperature to $220^{\circ} \mathrm{C}$, but decreasing the reaction time to $1.5 \mathrm{~h}$ and $4.5 \mathrm{~h}$, the compositions were comparable with the previous variations. Entry 4 to 6 , and entry 5 to 7 in Table 4 are to

Table 2. The reaction of diethyl phenylphosphonate (1) with ionic liquids in ethanol.

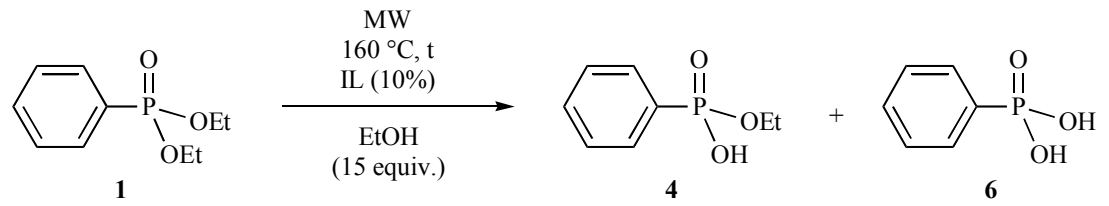

\begin{tabular}{|c|c|c|c|c|c|}
\hline \multirow[b]{2}{*}{ Entry } & \multirow[b]{2}{*}{ IL } & \multirow[b]{2}{*}{ t (h) } & \multicolumn{3}{|c|}{ Composition $(\%)^{a}$} \\
\hline & & & $\begin{array}{c}1 \\
M+H=215^{b}\end{array}$ & $\begin{array}{c}4 \\
M+H=187^{b}\end{array}$ & $\begin{array}{c}6 \\
M+H=159^{b}\end{array}$ \\
\hline 1 & {$[\mathrm{bmim}]\left[\mathrm{BF}_{4}\right]$} & 3.5 & 100 & 0 & 0 \\
\hline 2 & {$[\mathrm{emim}]\left[\mathrm{HSO}_{4}\right]$} & 3.5 & 58 & 38 & 4 \\
\hline 3 & {$[\mathrm{emim}]\left[\mathrm{HSO}_{4}\right]$} & 6 & 51 & 44 & 5 \\
\hline
\end{tabular}

${ }^{a}$ On the basis of relative ${ }^{31} \mathrm{P}$ NMR integrals

${ }^{b}$ Confirmed by LC-MS

Table 3. The transformation of dibutyl phenylphosphonate (3) with ionic liquids in butanol.

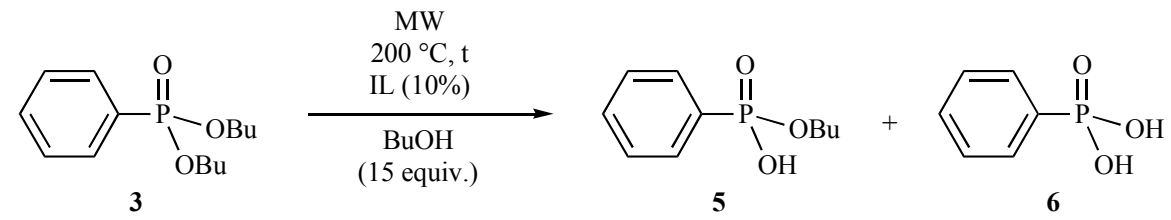

\begin{tabular}{|c|c|c|c|c|c|c|}
\hline \multirow[b]{2}{*}{ Entry } & \multirow[b]{2}{*}{ IL } & \multirow[b]{2}{*}{$\mathbf{T}\left({ }^{\circ} \mathbf{C}\right)$} & \multirow[b]{2}{*}{ t (h) } & \multicolumn{3}{|c|}{ Composition (\%) ${ }^{a}$} \\
\hline & & & & $\begin{array}{c}3 \\
\mathbf{M}+\mathbf{H}^{=}=271^{b}\end{array}$ & $\begin{array}{c}5 \\
M+H^{\prime}=215^{b}\end{array}$ & $\begin{array}{c}6 \\
M+H=159^{b}\end{array}$ \\
\hline 1 & {$[\mathrm{bmim}]\left[\mathrm{BF}_{4}\right]$} & 200 & 2 & 100 & 0 & 0 \\
\hline $2^{c}$ & {$[\mathrm{emim}]\left[\mathrm{HSO}_{4}\right]$} & 200 & 2 & 12 & 53 & 36 \\
\hline 3 & {$[\mathrm{emim}]\left[\mathrm{HSO}_{4}\right]$} & 200 & 2.5 & 4 & 40 & 56 \\
\hline 4 & {$[\mathrm{emim}]\left[\mathrm{HSO}_{4}\right]$} & 200 & 3.5 & 0 & 37 & 63 \\
\hline
\end{tabular}


Table 4. The dealkylation of diethyl phenylphosphonate (1) with ionic liquids in the absence of solvent.

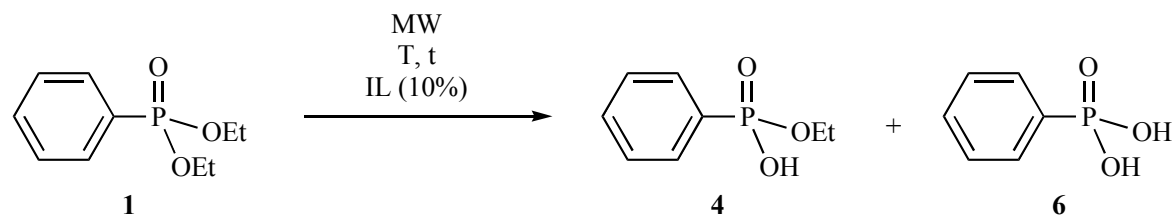

\begin{tabular}{|c|c|c|c|c|c|c|}
\hline \multirow[b]{2}{*}{ Entry } & \multirow[b]{2}{*}{ IL } & \multirow[b]{2}{*}{$\mathbf{T}\left({ }^{\circ} \mathrm{C}\right)$} & \multirow[b]{2}{*}{$\mathbf{t}(\mathbf{h})$} & \multicolumn{3}{|c|}{ Composition (\%) ${ }^{a}$} \\
\hline & & & & $\begin{array}{c}1 \\
M+H=215^{b}\end{array}$ & $\begin{array}{c}4 \\
M+H\end{array}=187^{b}$ & $\begin{array}{c}6 \\
M+H=159^{b}\end{array}$ \\
\hline 1 & {$[\mathrm{bmim}]\left[\mathrm{BF}_{4}\right]$} & 200 & 3.5 & 70 & 24 & 5 \\
\hline 2 & {$[\mathrm{bmim}]\left[\mathrm{BF}_{4}\right]$} & 220 & 4 & 21 & 21 & 58 \\
\hline 3 & {$[\mathrm{bmim}]\left[\mathrm{BF}_{4}\right]$} & 220 & 6.5 & 0 & 27 & 73 \\
\hline 4 & {$[\mathrm{emim}]\left[\mathrm{HSO}_{4}\right]$} & 200 & 2 & 19 & 36 & 45 \\
\hline 5 & {$[\mathrm{emim}]\left[\mathrm{HSO}_{4}\right]$} & 200 & 5 & 0 & 13 & 87 \\
\hline 6 & {$[\mathrm{emim}]\left[\mathrm{HSO}_{4}\right]$} & 220 & 1.5 & 15 & 26 & 59 \\
\hline 7 & {$[\mathrm{emim}]\left[\mathrm{HSO}_{4}\right]$} & 220 & 4.5 & 0 & 20 & 80 \\
\hline
\end{tabular}

${ }^{a}$ On the basis of relative ${ }^{31} \mathrm{P}$ NMR integrals

${ }^{b}$ Confirmed by LC-MS

Table 5. The dealkylation of dibutyl phenylphosphonate (3) with ionic liquids in the absence of solvent.

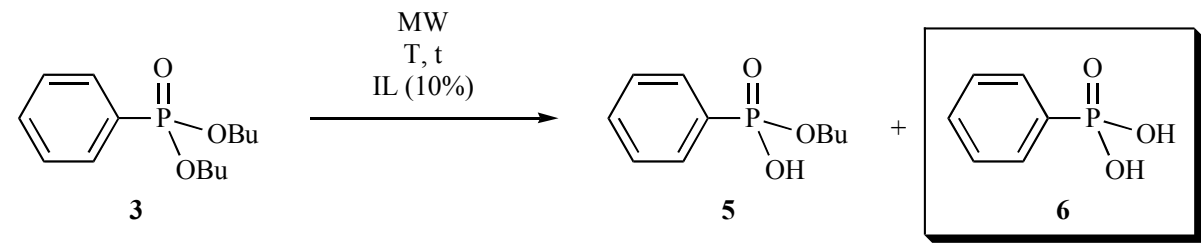

\begin{tabular}{|c|c|c|c|c|c|c|}
\hline \multirow[b]{2}{*}{ Entry } & \multirow[b]{2}{*}{ IL } & \multirow[b]{2}{*}{$\mathbf{T}\left({ }^{\circ} \mathrm{C}\right)$} & \multirow[b]{2}{*}{$\mathbf{t}(\mathbf{h})$} & \multicolumn{3}{|c|}{ Composition $(\%)^{a}$} \\
\hline & & & & $\begin{array}{c}3 \\
\mathbf{M}+\mathbf{H}=\mathbf{2 7 1 ^ { b }}\end{array}$ & $\begin{array}{c}5 \\
M+H^{\prime}=215^{b}\end{array}$ & $\begin{array}{c}6 \\
M+H=159^{b}\end{array}$ \\
\hline 1 & {$[\mathrm{bmim}]\left[\mathrm{BF}_{4}\right]$} & 200 & 2 & 92 & 8 & 0 \\
\hline 2 & {$[\mathrm{bmim}]\left[\mathrm{BF}_{4}\right]$} & 200 & 3.5 & 40 & 50 & 10 \\
\hline 3 & {$[\mathrm{bmim}]\left[\mathrm{BF}_{4}\right]$} & 220 & 4 & 7 & 21 & 72 \\
\hline 5 & {$[\mathrm{bmim}]\left[\mathrm{BF}_{4}\right]$} & 220 & 7 & 2 & 9 & 89 \\
\hline $6^{c}$ & {$[\mathrm{emim}]\left[\mathrm{HSO}_{4}\right]$} & 200 & 2 & 13 & 22 & 65 \\
\hline 7 & {$[\mathrm{emim}]\left[\mathrm{HSO}_{4}\right]$} & 200 & 4 & 0 & 3 & 97 \\
\hline
\end{tabular}

${ }^{a}$ On the basis of relative ${ }^{31} \mathrm{P}$ NMR integrals

${ }^{b}$ Confirmed by LC-MS

${ }^{c}$ Performing the reaction in the presence of $30 \%$ of the IL, the composition was $9 \%$ of $3,3 \%$ of $\mathbf{5}$ and $88 \%$ of $\mathbf{6}$.

be compared. The double fission of the $-\mathrm{P}(\mathrm{O})(\mathrm{OEt})_{2}$ moiety of ester 1 to afford the diacid (6) took place in a selectivity of $80-87 \%$.

Dibutyl phenylphosphonate $\mathbf{3}$ was also subjected to MW irradiation in the presence of different ILs in the absence of any solvent. The experimental data were summarized in Table 5. The irradiation of $\mathrm{PhP}(\mathrm{O})(\mathrm{OBu})_{2}$ at $200{ }^{\circ} \mathrm{C}$ for $2 \mathrm{~h}$ in the presence of $10 \%$ of $[\mathrm{bmim}]\left[\mathrm{BF}_{4}\right]$ took place in only a low conversion, affording $8 \%$ of the ester-acid 5 (Table 5/Entry 1). However, after a $3.5 \mathrm{~h}$ heating, the conversion was $60 \%$, indicating the presence of $50 \%$ of the ester-acid 5 and $10 \%$ of the acid (6) (Table 5/Entry 2). The treatment at $220{ }^{\circ} \mathrm{C}$ for $4 \mathrm{~h}$ resulted in a mixture of $7 \%(3), 21 \%(5)$, $72 \%$ (6) (Table 5/Entry 3). After a $7 \mathrm{~h}$ reaction time, the conversion was almost complete leading to a mixture containing only $9 \%$ of the ester-acid (5), along with $89 \%$ of diacid 6 (Table 5/Entry 5). Applying $[\mathrm{emim}]\left[\mathrm{HSO}_{4}\right]$, the fissions were again more efficient. After the treatment at $200{ }^{\circ} \mathrm{C}$ for $2 \mathrm{~h}$, the relative quantity of species $\mathbf{3}, \mathbf{5}$ and 6 was $13 \%, 22 \%$ and $65 \%$, respectively (Table 5/Entry 6). An irradiation of $4 \mathrm{~h}$ led practically selectively to the diacid (6) (Table 5/Entry 7). The conversions took place in the absence of water, even traces of water could not be present. After purification, phenylphosphonic acid (6) was obtained in a yield of $82 \%$. Combination of the shorter reaction time of $2 \mathrm{~h}$ with a larger amount $(30 \%)$ of the IL, catalyst led to the formation of phosphonic acid 6 in $88 \%$ (Table 5/footnote "c" to Entry 6). The latter experiments exemplify a novel conversion of a phosphonate to phosphonic acid. $[$ Emim $]\left[\mathrm{HSO}_{4}\right]$ proved to be more efficient than $[\mathrm{bmim}]\left[\mathrm{BF}_{4}\right]$.

Finally, the mixture of dibutyl phenylphosphonate (3), 15 equivalents of $n$-pentanol and $10 \%$ of $\left[\mathrm{bmim}^{-}\left[\mathrm{BF}_{4}\right]\right.$ was irradiated at $220^{\circ} \mathrm{C}$ in the hope of attaining a more selective reaction. After 2 $\mathrm{h}$, the fraction of diesters represented $7 \%$ of $\mathbf{3}, 11 \%$ of 7 and $30 \%$ of 
Table 6. The alcoholysis of dibutyl phenylphosphonate (3) with pentanol in the presence of ionic liquids in the absence of solvent.

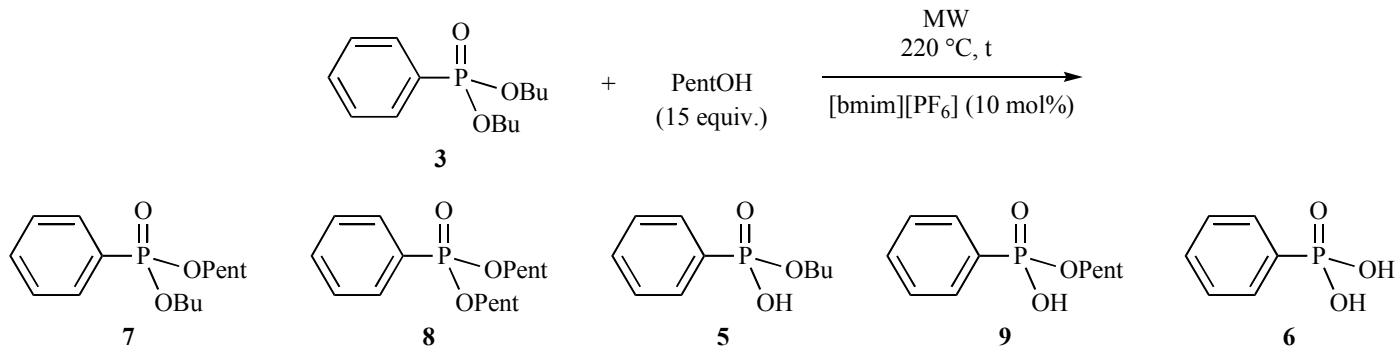

\begin{tabular}{|c|c|c|c|c|c|c|c|}
\hline \multirow[b]{2}{*}{ Entry } & \multirow{2}{*}{$\begin{array}{c}\text { t } \\
(\mathbf{h})\end{array}$} & \multicolumn{6}{|c|}{ Composition (\%) ${ }^{a}$} \\
\hline & & $\begin{array}{c}3 \\
M+H^{=} 271^{b}\end{array}$ & $\begin{array}{c}7 \\
M+H^{2}=285^{b}\end{array}$ & $\begin{array}{c}8 \\
M+H^{2}=299^{b}\end{array}$ & $\stackrel{5}{M+H^{\prime}}=215^{b}$ & $\stackrel{9}{M+H}=229^{b}$ & $\stackrel{6}{\mathrm{M}+\mathrm{H}=159^{b}}$ \\
\hline 1 & 2 & 7 & 11 & 30 & 0 & 52 & 0 \\
\hline 2 & 4.5 & 0 & 5 & 31 & 1 & 57 & 6 \\
\hline
\end{tabular}

${ }^{a}$ On the basis of combined ${ }^{31} \mathrm{P}$ NMR and LC-MS analysis

${ }^{b}$ Confirmed by LC-MS

$\mathbf{8}$, while among the ester-acids $\mathbf{5}$ and $\mathbf{9}$, only the latter (9) was present in $52 \%$ (Table 6/Entry 1). Following a reaction time of $4.5 \mathrm{~h}$, the starting ester (3) disappeared from the mixture. The esters formed by alcoholysis ( 7 and $\mathbf{8}$ ) were present in a portion of $5 \%$ and $31 \%$, respectively. Ester-acid 9 was formed with a noteworthy selectivity of $57 \%$ along with $6 \%$ of diacid 6 (Table 6/Entry 2 ). The monopentyl ester $(\mathrm{PhP}(\mathrm{O})(\mathrm{OPent})(\mathrm{OH}))(9)$ was prepared in a yield of $38 \%$ (Supplementary Material).

\section{EXPERIMENTAL}

\subsection{General}

The ${ }^{31} \mathrm{P},{ }^{13} \mathrm{C},{ }^{1} \mathrm{H}$ NMR spectra were taken on a Bruker DRX500 spectrometer operating at 202.4, 125.7 and $500 \mathrm{MHz}$, respectively. The couplings are given in Hz. HPLC-MS measurements were performed using a Shimadzu LCMS-2020 device equipped with a Reprospher $100 \mathrm{C} 18(5 \mathrm{~mm} ; 100 \times 3 \mathrm{~mm})$ column and positive-negative double ion source (DUIS) with a quadrupole MS analyzer in a range of $50-1000 \mathrm{~m} / \mathrm{z}$. The sample was eluted with gradient elution using eluent $\mathrm{A}(0.1 \%$ formic acid in water: acetonitrile 19: 1$)$ and eluent $B(0.1 \%$ formic acid in water: acetonitrile $1: 19)$. The flow rate was set to $1 \mathrm{~mL} \mathrm{~min}^{-1}$. The initial condition was $0 \% \mathrm{~B}$ eluent, followed by a linear gradient to $100 \% \mathrm{~B}$ eluent by $1 \mathrm{~min}$; from 1 to $3.5 \mathrm{~min} 100 \% \mathrm{~B}$ eluent was retained and from 3.5 to $4.5 \mathrm{~min}$, back to the initial condition with $5 \% \mathrm{~B}$ eluent and retained to $5 \mathrm{~min}$. The column temperature was kept at room temperature. High resolution mass spectrometric measurements were performed using a Waters Q-TOF Premier hybrid mass spectrometer in positive electrospray mode (Waters, Manchester, UK).

The experiments were carried out under anhydrous conditions. Unopened original bottles of the two IL-s were used. According to the supplier, the water content of the IL-s that we used in only microliters was $0.5-1 \%$. To check the situation, we heated the samples of IL-s at $80{ }^{\circ} \mathrm{C}$ under vacuum, but no measureble weight losses were experienced. The MW experiments were carried out in close vials.

\subsection{Use of the ${ }^{31} \mathbf{P}$ NMR Spectra in Quantitative Analysis}

The composition of the reaction mixtures was determined on the basis of the relative ${ }^{31} \mathrm{P}$ NMR integrals of the signals of the starting material and products.
3.3. General Procedure for the Attempted Alcoholysis of Diethyl Phenylphosphonate (1) with Butanol in the Presence of Ionic Liquids

To $0.50 \mathrm{mmol}(0.10 \mathrm{~g})$ of diethyl phenylphosphonate (1), $0.64 \mathrm{~mL} \quad(7.0 \mathrm{mmol})$ of butanol and $0.050 \mathrm{mmol} \quad(10 \mu 1$ [bmim] $\left[\mathrm{PF}_{6}\right], 7 \mu 1$ [emim] $\left[\mathrm{HSO}_{4}\right], 9 \mu 1$ [bmim] $\left.\left[\mathrm{BF}_{4}\right]\right)$ of ionic liquid were added. The mixture was irradiated in a CEM MW reactor at 200-220 ${ }^{\circ} \mathrm{C}$ for 2-3.5 h. After evaporation, the reaction mixture was analyzed by ${ }^{31} \mathrm{P}$ NMR spectroscopy and LC-MS. The results are shown in Table 1. The crude mixture obtained from the experiment marked by entry 7 of Table 1 was subjected to column chromatography (silica gel, DCM-MeOH 97:3) to afford ester-acid $\mathbf{5}$ in a yield of $22 \%$.

\subsubsection{Monobutyl Phenylphosphonate (5)}

${ }^{31} \mathrm{P}$ NMR: see Table 7; ${ }^{13} \mathrm{C}$ NMR $\left(\mathrm{CDCl}_{3}\right) \delta$ : $13.6\left(\mathrm{~s}, \mathrm{CH}_{3}\right), 18.7$ $\left(\mathrm{s}, \mathrm{CH}_{2}\right), 32.3\left(\mathrm{~d}, J=6.8, \mathrm{CH}_{2}\right), 65.6\left(\mathrm{~d}, J=5.8, \mathrm{OCH}_{2}\right), 128.3(\mathrm{~d}, J$ $\left.=15.2, \mathrm{C}_{3}\right), 129.2\left(\mathrm{~d}, J_{\mathrm{P}, \mathrm{C}}=193.4, \mathrm{C}_{1}\right), 131.4\left(\mathrm{~d}, J=10.1, \mathrm{C}_{2}\right)$, $132.1\left(\mathrm{~d}, J=3.0, \mathrm{C}_{4}\right) ;{ }^{1} \mathrm{H}$ NMR $\left(\mathrm{CDCl}_{3}\right) \delta: 0.84(\mathrm{t}, J=7.6,3 \mathrm{H}$, $\left.\mathrm{CH}_{3}\right), 1.33\left(\mathrm{~m}, 2 \mathrm{H}, 2 \mathrm{CH}_{2}\right), 1.58\left(\mathrm{~m}, 2 \mathrm{H}, \mathrm{CH}_{2}\right), 3.97(\mathrm{q}, J=6.8,2 \mathrm{H}$, $\left.\mathrm{OCH}_{2}\right), 7.37$ - 7.47 (m, 3H, Ar), $7.78-7.85$ (m, 2H, Ar), 12.56 (s, $1 \mathrm{H}, \mathrm{OH})$

\subsection{General Procedure for the Reaction of Diethyl Phenylphos-} phonates (1) in the Presence of Ionic Liquids and Ethanol

$0.50 \mathrm{mmol}(0.10 \mathrm{~g})$ of diethyl phenylphosphonate (1) was added to $0.41 \mathrm{~mL}(7.0 \mathrm{mmol})$ of ethanol and $0.050 \mathrm{mmol} 7 \mu \mathrm{l}$ [emim] $\left.\left[\mathrm{HSO}_{4}\right], 9 \mu 1[\mathrm{bmim}]\left[\mathrm{BF}_{4}\right]\right)$ of ionic liquid. The mixture was irradiated in a CEM MW reactor at $160{ }^{\circ} \mathrm{C}$ for $3.5 \mathrm{~h}$. After evaporation, the reaction mixture was analyzed by ${ }^{31} \mathrm{P}$ NMR spectroscopy. The results are shown in Table 2.

3.5. General Procedure for the Transformation of Dibutyl Phenylphosphonates (3) in the Presence of Ionic Liquids and Butanol

To $0.50 \mathrm{mmol}(0.13 \mathrm{~g})$, of dibutyl phenylphosphonate (3) $0.64 \mathrm{~mL} \quad(7.0 \mathrm{mmol})$ of butanol and $0.050 \mathrm{mmol} \quad(7 \mu 1$ [emim] $\left[\mathrm{HSO}_{4}\right], 9 \mu 1$ [bmim] $\left.\left[\mathrm{BF}_{4}\right]\right)$ of ionic liquid were added. The mixture was irradiated in a CEM MW reactor at $200{ }^{\circ} \mathrm{C}$ for $2-2.5 \mathrm{~h}$. After evaporation, the reaction mixture was analyzed by ${ }^{31} \mathrm{P}$ NMR spectroscopy. The results are shown in Table 3. 
Table 7. $\quad{ }^{31}$ P NMR and HRMS characterization of dialkyl phenylphosphonates (1 - 3, 7 and 8$)$, monoesters (4, 5 and 9) and phenylphosphonic acid (6).

\begin{tabular}{|c|c|c|c|c|c|}
\hline \multirow{2}{*}{\multicolumn{2}{|c|}{ Compounds }} & \multicolumn{2}{|c|}{$\delta^{31}$ P NMR } & \multicolumn{2}{|c|}{ HRMS } \\
\hline & & \multirow{2}{*}{$\begin{array}{c}\text { Found } \\
18.0 \\
\text { (DMSO) }\end{array}$} & \multirow{2}{*}{$\begin{array}{c}\text { Literature } \\
18.8[25] \\
\left(\mathrm{CDCl}_{3}\right)\end{array}$} & \multirow{2}{*}{$\begin{array}{c}\mathbf{M}+\mathbf{H}_{\text {found }} \\
215.0842\end{array}$} & \multirow{2}{*}{$\begin{array}{c}\mathbf{M}+\mathbf{H}_{\text {calculate }} \\
215.0837\end{array}$} \\
\hline \multirow{5}{*}{$\frac{n}{\vdots}$} & 1 & & & & \\
\hline & 2 & $\begin{array}{c}18.0 \\
(\mathrm{DMSO})\end{array}$ & $\begin{array}{c}17.7[29] \\
\left(\mathrm{CDCl}_{3)}\right.\end{array}$ & $265.0968^{*}$ & $265.0970^{*}$ \\
\hline & 3 & $\begin{array}{c}18.0 \\
\text { (DMSO) }\end{array}$ & $\begin{array}{c}18.8[30] \\
\left(\mathrm{CDCl}_{3}\right)\end{array}$ & $293.1278^{*}$ & $293.1283^{*}$ \\
\hline & 7 & $\begin{array}{c}17.9 \\
\text { (DMSO) }\end{array}$ & - & 285.1631 & 285.1620 \\
\hline & 8 & $\begin{array}{c}17.9 \\
\text { (DMSO) }\end{array}$ & $\begin{array}{c}18.9[30] \\
\left(\mathrm{CDCl}_{3}\right)\end{array}$ & 299.1781 & 299.1776 \\
\hline \multirow{3}{*}{ 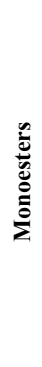 } & 4 & $\begin{array}{c}15.1 \\
\text { (DMSO) }\end{array}$ & $\begin{array}{l}15.0[25] \\
\text { (DMSO) }\end{array}$ & 187.0527 & 187.0524 \\
\hline & 5 & $\begin{array}{c}14.9 \\
(\mathrm{DMSO}) \\
18.8 \\
\left(\mathrm{CDCl}_{3}\right)\end{array}$ & $\begin{array}{c}20.5[29] \\
\left(\mathrm{CDCl}_{3}\right)\end{array}$ & 215.0841 & 215.0837 \\
\hline & 9 & $\begin{array}{c}14.6 \\
\text { (DMSO); } \\
19.8 \\
\left(\mathrm{CDCl}_{3}\right)\end{array}$ & $\begin{array}{c}22.2[30] \\
\left(\mathrm{CDCl}_{3}\right)\end{array}$ & 229.0996 & 229.0994 \\
\hline$\frac{\pi}{2}$ & 6 & $\begin{array}{c}13.2 \\
\text { (DMSO) }\end{array}$ & $\begin{array}{l}13.0[25] \\
\text { (DMSO) }\end{array}$ & 159.0209 & 159.0211 \\
\hline
\end{tabular}

*Identified as $\mathrm{M}+\mathrm{Na}$

3.6. General Procedure for the Dealkylation of Dialkyl phenylphosphonates $(1,3)$ in the Presence of Ionic Liquids in the Absence of Solvent

A mixture of $0.50 \mathrm{mmol}$ of dialkyl phenylphosphonate (1: $0.10 \mathrm{~g}, 3: 0.13 \mathrm{~g})$, and $0.050 \mathrm{mmol}\left(7 \mu \mathrm{l}\right.$ [emim] $\left[\mathrm{HSO}_{4}\right], 9 \mu \mathrm{l}$ [bmim] $\left.\left[\mathrm{BF}_{4}\right]\right)$ was stirred under $\mathrm{MW}$ conditions $(\max 150 \mathrm{~W})$ at $200-220{ }^{\circ} \mathrm{C}$ for $2-4 \mathrm{~h}$. The reaction mixture was analyzed by ${ }^{31}$ P NMR spectroscopy. The results are shown in Tables $\mathbf{4}$ and $\mathbf{5}$. Diacid 6 was obtained from the experiment, marked by Table $5 /$ Entry 7, by filtration and washing with $2 \times 0.5 \mathrm{~mL}$ of acetone in a yield of $82 \%$.

\subsubsection{Phenylphosphonic Acid (6)}

${ }^{31} \mathrm{P}$ NMR: see Table 7; ${ }^{13} \mathrm{C}$ NMR (DMSO- $\left.d_{6}\right) \delta: 128.6(\mathrm{~d}, J=$ $\left.14.2, \mathrm{C}_{3}\right), 131.0\left(\mathrm{~d}, J=9.9, \mathrm{C}_{2}\right), 131.4\left(\mathrm{~d}, J=3.0, \mathrm{C}_{4}\right), 134.3\left(\mathrm{~d}, J_{\mathrm{P}, \mathrm{C}}\right.$ $\left.=181.9, \mathrm{C}_{1}\right) ;{ }^{1} \mathrm{H}$ NMR $\left(\mathrm{DMSO}-d_{6}\right) \delta: 7.41-7.54$ (m, 3H, Ar), 7.66 $-7.73(\mathrm{~m}, 2 \mathrm{H}, \mathrm{Ar}), 9.60(\mathrm{~s}, 2 \mathrm{H}, 2 \mathrm{OH})$.

3.7. General Procedure for the Alcoholysis of Dibutyl Phenylphosphonate (3) with Pentanol in the Presence of Ionic Liquids in the Absence of Solvent

To $0.40 \mathrm{mmol}(0.10 \mathrm{~g})$, of dibutyl phenylphosphonate (3) $0.60 \mathrm{~mL}(5.6 \mathrm{mmol})$ of pentanol and $0.040 \mathrm{mmol}(7.5 \mu \mathrm{l})$ of [bmim $]\left[\mathrm{PF}_{6}\right]$ were added. The mixture was irradiated in a CEM MW reactor at $220^{\circ} \mathrm{C}$ for $2 \mathrm{~h}$. After evaporation, the reaction mixture was analyzed by ${ }^{31} \mathrm{P}$ NMR spectroscopy and LC-MS. The results are shown in Table 6. Ester-acid 9 was obtained from the experiment, marked by Table 6/Entry 2 by column chromatography (silica gel, DCM - MeOH $97: 3$ ) in a yield of $38 \%$.

\subsubsection{Monopentyl Phenylphosphonate (9)}

${ }^{31} \mathrm{P}$ NMR: see Table 7; ${ }^{13} \mathrm{C}$ NMR $\left(\mathrm{CDCl}_{3}\right) \delta: 14.0\left(\mathrm{~s}, \mathrm{CH}_{3}\right), 22.2$ (s, $\left.\mathrm{CH}_{2}\right), 27.6\left(\mathrm{~s}, \mathrm{CH}_{2}\right), 30.0\left(\mathrm{~d}, J=6.7, \mathrm{CH}_{2}\right), 66.0(\mathrm{~d}, J=6.0$,
$\left.\mathrm{OCH}_{2}\right), 128.3\left(\mathrm{~d}, J=15.2, \mathrm{C}_{3}\right), 129.0\left(\mathrm{~d}, J_{\mathrm{P}, \mathrm{C}}=193.8, \mathrm{C}_{1}\right), 131.4(\mathrm{~d}$ $\left.J=10.2, \mathrm{C}_{2}\right), 132.1\left(\mathrm{~d}, J=2.9, \mathrm{C}_{4}\right) ;{ }^{1} \mathrm{H}$ NMR $\left(\mathrm{CDCl}_{3}\right) \delta: 0.88(\mathrm{t}, J$ $\left.=6.7,3 \mathrm{H}, \mathrm{CH}_{3}\right), 1.30\left(\mathrm{~m}, 4 \mathrm{H}, 2 \mathrm{CH}_{2}\right), 1.65\left(\mathrm{~m}, 2 \mathrm{H}, \mathrm{CH}_{2}\right), 4.00(\mathrm{q}, J$ $\left.=6.8,2 \mathrm{H}, \mathrm{OCH}_{2}\right), 7.39-7.55(\mathrm{~m}, 3 \mathrm{H}, \mathrm{Ar}), 7.79-7.86(\mathrm{~m}, 2 \mathrm{H}, \mathrm{Ar})$, $12.69(\mathrm{~s}, 1 \mathrm{H}, \mathrm{OH})$.

Identification of the starting materials (1 and $\mathbf{3})$ and products (2-9) can be found in Table 7 .

\section{CONCLUSIONS}

In summary, the alcoholysis of dialkyl phenylphosphonates could not be performed neatly. However, in the presence of $10 \%$ of [emim] $\left[\mathrm{HSO}_{4}\right]$, the ester-acid formed after transesterification and mono fission of the phosphonate function was the major component. A similar reaction in the absence of alcohol could be finetuned to afford the phenylphosphonic diacid in a selective way. The partial or complete fission of the phosphonate moiety in the presence of suitable ionic liquids under dry conditions represents a novel transformation that is an alternative to hydrolysis.

\section{CONSENT FOR PUBLICATION}

Not applicable.

\section{AVAILABILITY OF DATA AND MATERIALS}

The data supporting the findings of the article is available within the article and supplementary material which is available on publishers website.

\section{FUNDING}

The research was supported by the National Research, Development and Innovation Office (K134318). N.Z.K. is grateful for the János Bolyai Research Scholarship of the Hungarian Academy of 
Sciences (BO/00130/19/7) and New National Excellence Program of the Ministry for Innovation and Technology from the source of the National Research, Development and Innovation Fund (ÚNKP20-5-BME-329).

\section{CONFLICT OF INTEREST}

The authors declare no conflict of interest, financial or otherwise.

\section{ACKNOWLEDGEMENTS}

Declared none.

\section{SUPPLEMENTARY MATERIAL}

Supplementary Material contains ${ }^{31} \mathrm{P},{ }^{13} \mathrm{C}$ and ${ }^{1} \mathrm{H}$ NMR spectra for compounds 5, 6 and 9, as well as ${ }^{31} \mathrm{P}$ NMR and LC-MS spectra for a few representative mixtures.

Supplementary material is available on the publisher's website along with the published article.

\section{REFERENCES}

[1] Quin, L.D. A Guide to Organophosphorus Chemistry; Wiley: NewYork, 2000 .

[2] Kiss, N.Z.; Keglevich, G. Methods for the preparation of phosphinates and phosphonates with a focus on recent advances In: Organophosphorus Chemistry - Novel Developments; Keglevich, G., Ed.; De Gruyter: Berlin, 2018, pp. $35-52$.

http://dx.doi.org/10.1515/9783110535839-002

[3] Kiss, N.Z.; Keglevich, G. An overview of the synthesis of phosphinates and phosphinic amides. Curr. Org. Chem., 2014, 18, 2673-2690. http://dx.doi.org/10.2174/1385272819666140829011741

[4] Kiss, N.Z.; Keglevich, G. Microwave-assisted direct esterification of cyclic phosphinic acids in the presence of ionic liquids. Tetrahedron Lett., 2016, 57, 971-974.

http://dx.doi.org/10.1016/j.tetlet.2016.01.044

[5] Kiss, N.Z.; Keglevich, G. Direct esterification of phosphinic and phosphonic acids enhanced by ionic liquid additives. Pure Appl. Chem., 2019, 91, 59-65. http://dx.doi.org/10.1515/pac-2018-1008

[6] Geshner, I.; Horton, D.P. Gelled hydrocarbons for oilfield processes, phosphate ester compounds useful in gellation of hydrocarbons and methods for production and use thereof. U.S. Patent 20110100633, September 12, 2011

[7] Froneman, M.; Modro, T.A. The titanium-mediated transesterification of phosphorous esters. Tetrahedron Lett., 1988, 27, 3327-3330. http://dx.doi.org/10.1016/0040-4039(88)85153-0

[8] Oswald, A.A. Synthesis of cyclic phosphorus acid esters by transesterification. Can. J. Chem., 1959, 37, 1498-1504.

http://dx.doi.org/10.1139/v59-220

[9] Fangrui, M.; Milford, A.H. Biodiesel production: a review. Bioresour. Technol., 1999, 70, 1-15.

[10] Harsági, N.; Szőllősi, B.; Kiss, N.Z.; Keglevich, G. MW irradiation and ionic liquids as green tools in hydrolyses and alcoholyses. Green Proc. Synth., 2020, 10(1), 1-10.

http://dx.doi.org/10.1515/gps-2021-0001

[11] Kosolapoff, G.M. Preparation of some mixed dialkyl phosphites. J. Am. Chem. Soc., 1951, 73, 4989.

http://dx.doi.org/10.1021/ja01154a528

[12] Aitken, R.A.; Collett, C.J.; Mesher, S.T.E. Convenient preparation of longchain dialkyl phosphates: synthesis of dialkyl phosphates. Synthesis, 2012, 44, 2515-2518.

http://dx.doi.org/10.1055/s-0031-1290823

[13] Kuskov, V.K.; Gradis, G.K. Reaction of diethyl phosphite with sodium alcoholates. Dokl. Akad. Nauk SSSR, 1953, 92, 323-324.

[14] Lewkowski, J.; Moya, M.R. The formation of dimethyl amino(pyrene-1yl)methylphosphonates in the Kabachnik-Fields reaction with dibenzyl phosphite, pyrene-1-carboxaldehyde and a non-aromatic amine in methanol. Phosphorus Sulfur Silicon Relat. Elem., 2017, 192, 713-718.

http://dx.doi.org/10.1080/10426507.2017.1308932

[15] Bálint, E.; Tajti, Á.; Drahos, L.; Ilia, G.; Keglevich, G. Alcoholysis of dialkyl phosphites under microwave conditions. Curr. Org. Chem., 2013, 17, 555562.

http://dx.doi.org/10.2174/1385272811317050010

[16] Tajti, Á.; Bálint, E.; Keglevich, G. Synthesis of ethyl octyl $\alpha$ aminophosphonate derivatives. Curr. Org. Synth., 2015, 13, 638-645. http://dx.doi.org/10.2174/1570179413666151218202757

[17] Bálint, E.; Tajti, Á; Tóth, N.; Keglevich, G. Continuous flow alcoholysis of dialkyl $H$-phosphonates with aliphatic alcohols. Molecules, 2018, 23(7), 1618. http://dx.doi.org/10.3390/molecules23071618 PMID: 29970851

[18] Kiss, N.Z.; Henyecz, R.; Keglevich, G. Continuous flow esterification of a $H$ phosphinic acid, and transesterification of $H$-phosphinates and $H$ phosphonates under microwave conditions. Molecules, 2020, 25(3), 719. http://dx.doi.org/10.3390/molecules25030719 PMID: 32046016

[19] Keglevich, G.; Bálint, E.; Tajti, Á.; Mátravölgyi, B.; Balogh, G.T.; Bálint, M.; Ilia, G. Microwave-assisted alcoholysis of dialkyl phosphites by ethylene glycol and ethanolamine. Pure Appl. Chem., 2014, 86, 1723-1728.

http://dx.doi.org/10.1515/pac-2014-060

[20] Troev, K.D. Chemistry and Application of H-Phosphonates; Elsevier: Amsterdam, 2006, p. 33.

[21] Bezdushna, E.; Ritter, H.; Troev, K.D. Microwave-assisted single-step synthesis of poly(alkylene hydrogen phosphonate)s by transesterification of dimethyl hydrogen phosphonate with poly(ethylene glycol). Macromol. Rapid Commun., 2005, 26, 471-476.

http://dx.doi.org/10.1002/marc.200400494

[22] Pretula, J.; Kaluzynski, K.; Szymanski, R.; Penczek, S. Transesterification of oligomeric dialkyl phosphonates, leading to the high-molecular-weight polyH-phosphonates. J. Polym. Sci., 1999, 37, 1365-1381.

http://dx.doi.org/10.1002/(SICI)1099-0518(19990501)37:9<1365::AIDPOLA17>3.0.CO;2-\#

[23] Sosnik, A.; Gotelli, G. Abraham. G.A. Microwave-assisted polymer synthesis (MAPS) as a tool in biomaterials science: How new and how powerful. Prog. Polym. Sci., 2011, 36, 1050-1078.

http://dx.doi.org/10.1016/j.progpolymsci.2010.12.001

[24] Keglevich, G.; Rádai, Z; Harsági, N.; Szigetvári, Á; Kiss, N.Z. A study on the acidic hydrolysis of cyclic phosphinates: 1-Alkoxy-3-phospholene 1oxides, 1-ethoxy-3-methylphospholane 1-oxide, and 1-ethoxy-3-methyl1,2,3,4,5,6-hexahydrophosphinine 1-oxide. Heteroatom Chem., 2017, 28, e21394.

http://dx.doi.org/10.1002/hc.21394

[25] Harsági, N.; Rádai, Z.; Kiss, N.Z.; Szigetvári, Á.; Keglevich, G. Two step acidic hydrolysis of dialkyl arylphosphonates. Mendeleev Commun., 2020, 30(1), 38-39.

http://dx.doi.org/10.1016/j.mencom.2020.01.012

[26] Harsági, N.; Rádai, Z.; Szigetvári, Á.; Kóti, J.; Keglevich, G. Optimization and a kinetic study on the acidic hydrolysis of dialkyl $\alpha$ hydroxybenzylphosphonates. Molecules, 2020, $25(17), 3793$. http://dx.doi.org/10.3390/molecules25173793 PMID: 32825450

[27] Rádai, Z.; Kiss, N.Z.; Keglevich, G. An overview of the applications of ionic liquids as catalysts and additives in organic chemical reactions. Curr. Org. Chem., 2018, 22, 533-556.

http://dx.doi.org/10.2174/1385272822666171227152013

[28] Li, C.; Saga, Y.; Onozawa, S.Y.; Kobayashi, S.; Sato, K.; Fukaya, N.; Han, L.B. Wet and dry processes for the selective transformation of phosphonates to phosphonic acids catalyzed by Brønsted acids. J. Org. Chem., 2020, 85(22), 14411-14419.

http://dx.doi.org/10.1021/acs.joc.0c00550 PMID: 32434328

[29] Henyecz, R.; Kiss, A.; Mórocz, V.; Kiss, N.Z.; Keglevich, G. Synthesis of phosphonates from phenylphosphonic acid and its monoesters. Synth. Commun., 2019, 49(20), 2642-2650.

http://dx.doi.org/10.1080/00397911.2019.1637894

[30] Kiss, N.Z.; Mucsi, Z.; Böttger, É.; Drahos, L.; Keglevich, G. A three-step conversion of phenyl- $H$-phosphinic acid to dialkyl phenylphosphonates including two microwave-assisted direct esterification steps. Curr. Org. Synth., 2014, 11(5), 767-772.

http://dx.doi.org/10.2174/1570179410666131212231130

DISCLAIMER: The above article has been published in Epub (ahead of print) on the basis of the materials provided by the author. The Editorial Department reserves the right to make minor modifications for further improvement of the manuscript. 